\title{
Practice of College English Teaching Reform Based on Online Open Course
}

\author{
Shan Kong ${ }^{1}$ \\ ${ }^{1}$ School of Foreign Studies, Yiwu Industrial \& Commercial College, Yiwu, Zhejiang, China \\ Correspondence: Shan Kong, School of Foreign Studies, Yiwu Industrial \& Commercial College, Yiwu, \\ Zhejiang Province, China.
}

Received: March 8, 2019 Accepted: April 16, 2019 Online Published: April 18, 2019

doi: 10.5539/elt.v12n5p156 URL: https://doi.org/10.5539/elt.v12n5p156

\begin{abstract}
Online open course has a significant impact on college English teaching, which brings about huge changes in college English teaching concepts, teaching modes, and teaching evaluations. This paper introduces and discusses the construction and application of college English online open course in a vocational college in China. And it also points out the clear goals of college English online open course in the future.
\end{abstract}

Keywords: online open course, college English, teaching reform

\section{Introduction}

With the advancement of educational technology and the gradual change of teaching concepts, the combination of information technology and classroom teaching has generally penetrated into education. In April 2015, the Ministry of Education of China issued the "Opinions of the Ministry of Education on Strengthening the Application and Management of Online Open Courses in Colleges and Universities", stating that high-quality online open courses should be built. The online open courses have practiced China's concept of building a lifelong learning society with characteristics of openness, convenience and interaction. The online open courses are favored by people including college students with their large-scale and free resources, which can be used without space and time constraints.

Based on the online courses, learners and learning communities interact with the online learning environment through a series of learning behaviors in order to complete learning tasks and assignments with specific learning objectives, which has had a profound impact on college classroom teaching.

\section{The Impact of Online Open Courses on College English Teaching}

The emergence and development of online open courses has brought about tremendous changes in college English teaching concepts, teaching modes, and teaching evaluations.

\subsection{Changing of Teaching Concepts}

The online open course has transformed our teaching concepts enormously. First of all, it makes learning process more participatory, exploratory and experiential, which naturally changes the roles of teachers and students. For students, the online learning can be done anywhere and the learning styles are quite flexible. However, they should learn and complete assignments more independently, and knowledge internalization is fulfilled mainly by themselves. On the other hand, the role of teachers is to guide, inspire and supervise students' learning process. This puts forward higher requirements on teachers' teaching ability and information quality. College English teachers should not only participate in curriculum implementation, tutoring, assessment, but also get involved in the construction of online course, including micro-course videos recording, and high-quality online open resources creating and updating. Therefore, the instructional design of the college English online open course should focus on the English learning tasks and activities, so that students can improve their English language skills in the practice of language learning. Teachers can use information technology to stimulate students' interest in learning English through a series of language activities such as English dubbing exercises, language-speaking games, semi-structured conversation experiences with AI, role-playing and English micro video making. 


\subsection{Changing of Teaching Modes}

The online open course has greatly changed college English teaching mode. Online learning contains video lectures, quizzes, unit tests, and supplementary resources. In addition, the online course platform also has a discussion forum between teachers and students for answering questions. Offline classroom teaching is an extension and expansion of online courses. Therefore, teachers should use a mixed teaching mode that combines online and offline teaching activities. It is totally different from the traditional classroom teaching mode. That is, students watch video lectures, take notes, join discussions and complete quizzes, assignments online, and teachers give them guidance and supervision both online and offline with their learning difficulties and extend their language knowledge and skills.

In the classroom teaching, teachers use the online platform data such as the length of video viewing, test scores, number and quality of notes and posts in the discussion forum, online communication frequencies, to learn about the effects of students' online learning and their learning weaknesses. Thus, teachers can provide help for students' learning difficulties, answer their questions. During this process, teachers mainly use the TBLT (Task-based Language Teaching) and the situational language teaching to create a real language situation for students, and arrange corresponding tasks, so that students can master the language knowledge and improve their language skills by completing tasks in language practice.

\subsection{Changing of Teaching Evaluations}

The online open course has also altered college English teaching evaluation methods.A combination of process evaluation and summative evaluation is mainly adopted by teachers. The data of the process evaluation is intelligently generated by the online course platform, which can objectively record the students' entire learning process. Students' online learning data such as video watching, note-taking, homework and quizzes completing, and communication frequencies in discussion forum will be included in the teaching evaluation, which not only mobilizes students' initiative and enthusiasm, but also plays a role in regulating teaching. The regulatory role of the evaluation data is reflected both in the before-class and after-class stages.

Before class, teachers use students' online learning data such as the length of the video viewing, the completion of before-class assignments to accurately analyze students' learning effects, thereby adjust teaching difficulties and strategies. After class, teachers can discover the problems in the teaching from the students' test scores, self-assessment forms and mutual evaluation forms, conduct teaching diagnosis and reflection, and eventually improve future teaching. Furthmore, teachers can provide immediate feedbacks to students for their questions and obstacles encountered in online learning through interactions in discussion forum.

\section{Construction and Application of College English Online Open Course}

Since 2016, our online course team including 5 English teachers has created an online open course for college English. The course is centered on student development, which aims to cultivate students' English communicative competence in daily life and business occasions, and promote their self-learning ability. Furthermore, the course can make the students adapt to the "Internet Plus" new learning experiences. We make full use of information technology to conduct reform and innovation in curriculum system, teaching materials and teaching methods. We provide the students with online and offline mixed learning platform and integrate high-quality online learning resources into our English language teaching. The course offers practical, scientific and reasonable teaching evaluation, which can enhance the students' self-learning ability and English application skills comprehensively.

\subsection{Constructing Teaching Materials of College English Online Open Course}

By using functional vocabulary and authentic simulated business situations, this course covers 10 useful topics including Receptions and Welcoming, Dining, Hotel Accommodations, Travel, Attending Trade Fairs, Market Surveys, Product Presentations, Business Negotiation, Packaging and Delivery, and Settling Complaints. It is designed to help learners communicate with people from all over the world in various business situations with confidence. For each topic, there are three parts including useful sentences, listening exercises, and a role-play conversation. The course is open to non-English majors in vocational colleges.

\subsection{Reforming College English Teaching Mode Based on Online Open Course}

Based on the college English online open course, we adopt an online and offline mixed teaching mode, and information technology is applied to all aspects of teaching. The process is as the following steps:

Step 1: Teachers upload course videos, and give students tasks and assignments.

Step 2: Students watch videos, take notes, finish assignments, and post in the discussion forum online. 
Step 3: Teachers give feedbacks to students, answer their questions and solve their problems. Teachers try to be organizers and instructors both online and offline.

Step 4: Students practice English language skills through well-designed tasks and activities under the guidence and supervision of teachers in the classroom.

Step 5: Teachers upload the next round of course videos, and give students tasks and assignments.

Step $6 \ldots$

\subsection{Features of the College English Online Open Course}

There are four remarkable features of our college English online open course.

Firstly, ability oriented. This course implements the requirements of "enhancing practicality, strengthening listening and speaking of English language" in vocational colleges, and has carried out in-depth teaching reform in the training of oral English ability. We organized the students to conduct surveys on the English usage of market dealers and business owners in Yiwu, so as to learn about the regular transaction process and communication content of international business occasions, and be able to select the content of the curriculum that is applicable to a wide range of applications, timeliness and practicality.

Secondly, a mixed learning and teaching community. The students conduct individual learning, group learning and public learning through the online learning platform. The teachers use the online and offline mixed teaching mode to provide help for the students' learning difficulties, answer their questions, discuss solutions in the public discussion forum and group discussion forum, which enhance comprehensive interactions between teachers and students.

Thirdly, smart offline learning activities under technical support. Apart from the course videos and assignments online, we also recommend some useful and interesting English learning APPs for our students such as "English Fun Dubbing", "Speaking Fluently in English", which can help them learn English independently and individually. In addition, we use classroom teaching management software including "Blue Ink Cloud Class" and "Thumb Class", which have the functions of scanning code, real-time recording of classroom performance, and quizzes to improve the students' participation in class.

Fourthly, multi-dimensional evaluation system. The evaluation subjects are composed of teachers, students, and learning community. According to the online learning platform statistics, which contain a series of indicators such as task completion (video viewing, note-taking, quizzes), cooperation (group learning tasks, discussion forum posting), learning effects (test scores, self-assessment forms and mutual evaluation forms), the evaluation system can make a procedural and multi-dimensional evaluation of the students' learning achievements.

\subsection{Implementation Effects of the College English Online Open Course}

By the end of January 2019, the course has been put into use for 3 semesters and 6710 students have completed the course. More than 200 students from the other two vocational colleges in Zhejiang Province of China also took this course.

Starting from the students' learning needs and English language foundation, we use the practical teaching methods that are appropriate to learning characteristics of the students in vocational colleges. Our teaching is student-centered, and the teaching methods we use are flexible and diverse. Our teaching focuses on cultivating students' practical ability to use English language, which can effectively mobilize the students' enthusiasm for learning and develop their good study habits. During the teaching process, the communication and interaction between teachers and students are emphasized. The online and offline teaching and learning activities can support each other, we have achieved good teaching effects and successfully improved the students' English listening and speaking skills.

Through the interview and questionnaire feedbacks, our students generally have positive and recognized attitudes toward this course. They believe that the course shows advanced learning philosophy and explores the application of modern educational technology in teaching and learning. In their opinions, the teachers integrate contents of textbooks, micro-course videos and English learning Apps to enable them to complete various tasks and improve their English language skills in real and natural language situations. According to the data of the students' evaluation of teachers in the latest two semesters, the scores of the lecturers of college English are all above 90 marks, which is excellent level. The students from other vocational colleges who have taken this course also have a good evaluation of the course. They believe that the course learning can be carried out at any time with fragmented time, which is convenient, efficient, and effective.

By taking the course, the College English Proficiency Test results of our students have been significantly 
improved. In the test of May 2018, the pass rate exceeded the national average pass rate by $20 \%$. In August 2018, our college English online open course has been approved by the Zhejiang Provincial Education Department. Now it has a wide range of influence in vocational colleges in Zhejiang Province, which attracts many English teachers from other vocational colleges to come to study.

\subsection{Limitations}

During the process of building and applying the course, we found that the quality of micro-course videos has a great influence on students' interest in learning. Some students complained in the interview, "The videos can do better", "The videos are a little boring". It makes it clearly that the production of high-level teaching videos not only requires teachers to have information technology literacy, but also have a clear understanding of the characteristics of their students. It is a big challenge for our team to make and present the teaching videos in appropriate forms for our students, and which will definitely be the focus of our teaching research.

\section{Future Goals of College English Online Open Course}

In the future construction of our college English online open course, our online course team will continue to improve the quality of micro-course videos, update the course materials, make it a high-quality online open course with distinctive features, abundant resources and fruitful achievements, which will adapt to the development of educational information, serve the teachers and students of vocational colleges. The core objective of this course is to enable each learner to express and communicate in a proper way in English in daily life and business occasions, and have good intercultural communication skills. We will make efforts to achieve the following goals:

Firstly, we will open our course to the students of vocational colleges 10 consecutive sessions, and it is estimated that at least 2,000 students are able to take this course for each session.

Secondly, we will open our course to the public so as to benefit more English learners. It is estimated that some 500 off-campus learners are able to take this course for each session, and we are planning to issue learning certificates to the off-campus learners.

Thirdly, we will establish an E-tutor team with at least 20 teachers, and conduct 3 online tutorings per week to answer questions for learners and stimulate the learners' enthusiasm and participation in learning English.

Fourthly, we will conduct the New Textbook Project of Colleges and Universities of the "13th Five-Year Plan" of Zhejiang Province, and compile a high-quality textbook A Course of English Practice-Business English Listening and Speaking matching with our college English online open course, so as to benefit the teachers and students of vocational colleges.

\section{References}

Bárkányi, Z., \& Melchor-Couto, S. (2017). Foreign Language Anxiety on a Massive Open Online Language Course. https://doi.org/10.14705/rpnet.2017.eurocall2017.683

Fred, G. M. (2012). Will Massive Open Online Courses Change How We Teach? Communications of the ACM, 55, 26-28. https://doi.org/10.1145/2240236.2240246

Lao, Q., \& Luan, L. J. (2016). Exploration and Design of Higher Vocational English Education from the Perspective of MOOC. Beijing: Higher Education press Press.

Li, G. (2016). The Role Orientation of Foreign Language Teachers and Their Professional Development from the Perspective of MOOCs. Heilongjiang Researches on Higher Education, 4, 158-160.

Li, M. L. (2013). Decoding M00C: A pedagogical study of large-scale online open courses. Beijing: Tsinghua University Press.

Liu, H. (2016). To Merge Online Courses into Higher School Curriculum and Teaching System: Obstacles and Their Removal. Journal of Higher Education, 5, 68-72.

Lv, S. L. (2015). China Online Education Industry Blue Book. Beijing: Peking University Press.

Ministry of Education of China. (2015). Opinions on Strengthening the Application and Management of Online Open Courses in Colleges and Universities. Retrieved from http://www.gov.cn/xinwen/2015-04/28/content 2854088.htm

Rodriguez, C. O. (2012). MOOCs and the AI-Stanford Like Courses: Two Successful and Distinct Course Formats for Massive Open Online Courses. European Journal of Open, Distance and E-Learning, 1-13.

Song, L. Q. (2014). Research on Challenges of MOOC to Teachers and Professional Development.China 
Educational Technology, 9, 139-143.

Tang, M. (2015). MOOC Revolution: How the Internet Changes Education. Beijing: CITIC Publishing House.

Zhao, G. D. (2015). A Course of Practice for Micro-class, Flipping Classroom and MOOC. Beijing: Peking University Press.

\section{Copyrights}

Copyright for this article is retained by the author(s), with first publication rights granted to the journal.

This is an open-access article distributed under the terms and conditions of the Creative Commons Attribution license (http://creativecommons.org/licenses/by/4.0/). 